\title{
Investing into Siberian Human \\ Potential Development: \\ Investment into "Export" Professionals \\ or Growth of Local Human Capital Assets?
}

Irina P. Vorontsova

and Liudmila K. Vitkovskaya*

Siberian Federal University

79 Svobodny, Krasnoyarsk, 660041, Russia

Received 27.07.2016, received in revised form 19.09.2016, accepted 27.10.2016

The article studies the problem of human capital assets of Siberian and Arctic zones based on the example of the Krasnoyarsk Territory (Krai).

Keywords: human capital assets, the quality of life, professional composition settlement.

The research is carried out with the financial support of Russian Humanitarian Science Foundation (RHSF) within the project titled "Methodological Approaches to Migration Flows Monitoring for the Formation of Living standards Control System in the Siberian Regions and Differentiated Policy Development", Project number 15-12-24008.

DOI: 10.17516/1997-1370-2016-9-11-2697-2705.

Research area: economics.

\section{Introduction}

Within the past 15 years, the following tendencies in the socioeconomic development of the Krasnoyarsk Territory (Krai) have developed:

- rapid growth of population (by $81 \%$ due to migration gain); ageing of population (specific gravity of people over the working age is much higher than $12 \%$ ); decrease of the working-aged population, and, as a result, growth of dependency on each employed person in the local economy.

- improvement of living standards in the region: emergence of new pre-school education facilities, leisure and sports facilities, higher availability of education, public health, culture services.

- growth of the cash wages of the population with high differentiation of wages by groups of population, slowdown of labour productivity growth;

- relatively high scientific, educational, innovative potential with the low demand for innovations in the real sector; achievement of average Russian indicators of research activity development in the publication activity and export of technologies;

(C) Siberian Federal University. All rights reserved

* Corresponding author E-mail address: vip64@mail.ru; LVitkovskaya@sfu-kras.ru 
- establishment of structural disproportions in the labour market for more than a half of all vacancies: lots of low-qualification vacancies and problems with finding suitable jobs, unemployment among young people and college graduates (up to $45 \%$ );

- outflow of highly-skilled specialists from the region.

Professional education of the Krasnoyarsk Territory (Krai) today ensures sufficient level of the graduates' competences and skills to work in different professional spheres due to their way of thinking and work management capacity. It provides their competitive ability in the global labour market in case of the third professional revolution and, at the same time, causes intensive outflow of young specialists from the city and the region.

Professional education system of the Krasnoyarsk Territory (Krai) includes a network of elementary, secondary, higher and additional professional education facilities. In total, on 05.09.2015 in the Krasnoyarsk Territory (Krai) the number of children studying at municipal general education facilities was 306371 . Over 43.2 thousand people study at 7 professional education facilities of the region. The finance provided to the regional education system is expected to increase in the year 2015 by 1.4 billion roubles.

Moreover, in the territory of the region there are 10 federal state universities and 1 private one, educating 98997 students. In the past five years, the efficiency of scientific and research activity of the local scientists has increased. Siberian Federal University has gained a higher position in Scimago Institutions Rankings (http://www.scimagoir.com). It is also seen in Russian Science Quotation Index and in Scopus: the total number of works published by SFU, other universities of the region and research institution workers in Russian and foreign journals with an impact factor has risen by almost $10 \%$ in the past 9 years, reaching 9 212 in the year 2015. However, it is still much less than in other Siberian regions (Novosibirsk and Tomsk Oblasts). In the year 2015, SFU was admitted to the national programme of supporting the largest Russian universities titled "5-100 Project", aimed at increasing competitive ability of the leading Russian universities and strengthening their positions in various international ratings.

The Krasnoyarsk Territory (Krai) has a well-developed scientific system; 11 scientific institutions of the region have been integrated into the "Federal Research Centre 'Krasnoyarsk Scientific Centre of the Siberian Branch of Russian Academy of Sciences"”.

In the past years, the Krasnoyarsk Territory (Krai) has entered the top-ten regions receiving the greatest investments into their general capital assets, surpassing the average Russian investment growth rates (from 2002 to 2015, the volume of investments in the region has increased by 4.5 times, while average Russian increase was evaluated as by 2.2 times). The territory is the place for fulfilment of such large investment projects as comprehensive development of the Lower Angara District, Vankor deposit cluster exploration, construction of the main "KuyumbaTaishet" oil line for transporting oil from the South of Evenkia, and development of Siberian Federal University.

The Krasnoyarsk Territory (Krai) innovative development strategy aims at the annual GRP growth rate of $3.5-5 \%$, growth and structural transformation of the regional economy by increasing the share of processing industries and innovative activities, development of social, housing, and utility spheres of the region by means of high investment activity with the annual investment volume of $18-20 \%$ of the GRP (the Krasnoyarsk Territory (Krai). Official portal.http://www.krskstate.ru/innovation_science/ strategy). 
Despite the relatively high level of investment into the regional economy, the growth of its innovative potential is unstable and drags behind the figures expected by "The Krasnoyarsk Territory (Krai) Innovative Development Strategy Till the Year 2020". The dynamics of the key indicators determining the innovative development of the regional economy in the years 2010-2014 based on the data provided by the Territorial Body of the Federal Service of State Statistics for the Krasnoyarsk Territory (Krai) (Krasnoyarskstat) are shown in Tables 1-4.

The data shown above demonstrates that the innovative development indicators stipulated in

Table 1. Higher education institutions (at the beginning of the academic year)

\begin{tabular}{|l|c|c|c|c|c|}
\hline & $2010 / 11$ & $2011 / 12$ & $2012 / 13$ & $2013 / 14$ & $2014 / 15$ \\
\hline $\begin{array}{l}\text { Number of education facilities - total } \\
\text { including: }\end{array}$ & 12 & 12 & 11 & 11 & 10 \\
\cline { 2 - 6 } & & & & & \\
\hline State facilities & 11 & 11 & 10 & 10 & 9 \\
\hline Private facilities & 1 & 1 & 1 & 1 & 1 \\
\hline Number of students - total, thousand people & 121.8 & 111.9 & 110.0 & 102.5 & 96.1 \\
\hline Including: in & & & & & \\
\hline State education facilities & 110.0 & 100.7 & 98.8 & 92.2 & 85.9 \\
\hline Number of education facilities students per 10 000 people & 431 & 394 & 387 & 359 & 336 \\
\hline Including state facilities students & 389 & 355 & 347 & 323 & 300 \\
\hline
\end{tabular}

Table 2. Professional education facilities providing advanced training for qualified workers

\begin{tabular}{|l|c|c|c|c|}
\hline & 2010 & 2011 & 2012 & 2013 \\
\hline Number of professional education facilities & 75 & 75 & 75 & 74 \\
\hline Number of students & & & & \\
\hline Total, thousand people & 24.8 & 23.6 & 22.8 & 22.4 \\
\hline Per 10 000 people & 88 & 83 & 80 & 78 \\
\hline Admitted for training, thousand people & 18.9 & 16.6 & 16.1 & 15.3 \\
\hline Graduated qualified workers - total, thousand people & 16.4 & 14.5 & 13.6 & 12.5 \\
\hline Per 10 000 employed people & 114 & 101 & 95 & 88 \\
\hline
\end{tabular}

Table 3. Number of used advanced production technologies

\begin{tabular}{|l|c|c|c|c|c|}
\hline & 2010 & 2011 & 2012 & 2013 & 2014 \\
\hline All advanced production technologies & 1937 & 1979 & 2261 & 2388 & 2445 \\
\hline
\end{tabular}

Table 4. Technological innovations

\begin{tabular}{|l|c|c|c|c|c|}
\hline & 2010 & 2011 & 2012 & 2013 & 2014 \\
\hline $\begin{array}{l}\text { Expenses for technological organization of } \\
\text { enterprises engaged in innovative facilities (million } \\
\text { roubles) }\end{array}$ & 14600.0 & 19643.9 & 24979.5 & 67700.3 & 84718.5 \\
\hline Number of created advanced technologies & 6 & $\mathrm{x}$ & 38 & 24 & 26 \\
\hline
\end{tabular}


the Innovative Development Strategy have hardly changed in the past four years.

Just like essential services, the social sphere of the region shows high key living standards indicators, such as number of commissioned residential houses per capita and retail trade turnover. Within the past 4 years, the Krasnoyarsk Territory (Krai) has gained its place among the 8 leaders of Russia in HDI, at the same time maintaining the highest working-age population outflow rate.

The population outflow is not a problem; it is a normal phenomenon which shows a good level of Siberian and Arctic human potential. The problem is the qualitative and quantitative indicators of the migration inflow ("who comes and does anyone come?"). The idea of mobility is tightly connected to the democracy development tendencies of the Russian Federation. Along with that, the requirements for providing high population mobility of the Krasnoyarsk Territory (Krai) contradicts the socioeconomic, natural and geographic realities of the Siberian regions.

The development of new regional administration approaches shall actualize prerequisites for the advantageous conditions for human potential development, as they are based on the existing high level of general and professional education, sociocultural sphere, scientific and innovative facilities and production clusters formation capacity of the region.

\section{Conceptual basis of the research}

Migration dynamics are caused by the quality of life tendencies of both "donor territories" and "recipient territories".

The quality of life problem has been studied in the works of various economists and sociologists: A. Smith, K. Marx, J. Schumpeter, R. Crowford, R. Coase, D. North, O. Williamson, J. Buchanan, T. Schultz, G. Becker. Among Russian scientists we should remark Kedrov
B.M., Kugel' S.A., Gvishiani D.M., Maslennikov V.I., Inozemtsev V.V., Zavlin P.N., Stepin V.S., Pivovarova M.A., Shapovalov V.F., Rozova M.A., Sadovnichiy V.A., Akaev A.A., Korotaev A.V., Malkov S.Iu.

There are some contradictory points of view on the interdependence of the quality of life and the socioeconomic development level. The majority of researchers believe that high living standards are a consequence of economic growth: the main objective and development of a state as such are determined with the economic growth, while the freedom and social support of the population is the consequence of the economic growth of the country. The disciples of human development concept, inspired by Amartya Sen, criticize such approach and prove that the economic growth is, on the opposite, a consequence of human development and freedom.

Along with that, socioeconomic growth peculiarities are determined by $R \& D$ progress. In our opinion, $R \& D$ progress is the first factor for both economic growth and social development. Technology influences the features of labour, and, as a consequence, determines the opportunities for fulfilment of human potential, motives and needs. The R\&D progress determines the technological waves which, in their turn, allow achieving a certain level of well-being within a certain historical period, the type of labour, employment conditions and occupational structure.

All solutions concerning the social policy advantageous for $R \& D$ progress oriented on providing high the quality of life, shall be differentiated, considering the interests of all key active groups of population, not those of one average person.

The quality of life reflect the specificity of different population groups' aspirations for these or those aspects of socioeconomic conditions (B. Khasan, I. Vorontsova, L. Novopashina, 2014). 
It is the uniqueness of the active population groups' aspirations for the conditions suitable for research and business activities that creates certain challenges for the formation of socioeconomic conditions of life which, as a rule, form themselves according to some specific standards.

\section{Problem setting}

In the economy of the Krasnoyarsk Territory (Krai) the fourth technological wave is dominating with its share constituting, approximately, $84-85 \%$. Investments into culture, education, public health, sports, entrepreneurship of the Krasnoyarsk Territory (Krai) present only potential benefits which may be gained only provided that the activities based on the fifth technological wave develop.

Today's economy of the Krasnoyarsk Territory (Krai) claims its demand for lowqualified traditional jobs.

Generally, there have been the following tendencies in the labour market of the Krasnoyarsk Territory (Krai) within the past five years:

1) Employment reduction rate decrease;

2) Unemployment rate decrease and youth unemployment growth: around $40 \%$ of the unemployed have higher education;

3) Decrease of tension and stabilization of the current situation on the labour market.

However, the real occupation issue among the unemployed, especially among youth and qualified specialists remains open due to the accumulated structural disproportions of the market. In the year 2013 the average number of vacancies per one applicant was around 5 . At the same time, there are over 5 unemployed per each vacancy of a system administrator and around 7 applicants per each vacancy of an economist, mechanic or a lawyer. It is hard for the unemployed to find a job to match.
The current processes on the regional labour market are hardly different from those around Russia and the Siberian Federal District.

The current type of the Krasnoyarsk Territory (Krai) economy determines the following peculiarities of the local quality of life:

Environment pollution combined with severe natural and climatic conditions.

The habitat does not satisfy the requirements of the permanent residence environment due to the specificity of industrial exploration of the Krasnoyarsk Territory north which is frequently done with the rotation method. Around the whole territory of the Krasnoyarsk Territory (Krai) there are only 3 cities with the population over 100 thousand people (Krasnoyarsk, Achinsk, Norilsk). In the current natural and geographic conditions of the region, small towns and urban settlements cannot provide the modern living standards of urban life (telecommunications, market, everyday service, transport availability of other cultural and economic centres of the country and the world, high level of occupation supply differentiation; accessibility of higher education).

Low transport availability in the settlements.

Insufficiency of basic social services: education, public health, culture for the smallnumbered indigenous peoples due to their lifestyle (many representatives of the small-numbered indigenous peoples preserve their nomadic lifestyle). As a result, small-numbered indigenous peoples still face low level of education (or even illiteracy), high infant mortality rate, low life duration, small range of consumed food products and convenience goods.

There we observe highly differentiated accumulated level of wealth determined by single profile of the economy and some of its institutional and organizational peculiarities acting as a constraint for the economic growth. 
Conservation and deterioration of the labour market within the framework of obsolete dogma of the industrial economy development period, with the priority of the employer's requirements and "struggle" against innovations for the sake of preserving the "yesterday's" order of things. It is an obstacle on the way of forming a globally competitive economy of the region based on the modern information- and knowledge-based technologies.

Labour life quality and the unified development standards of the technical, technological and social spheres of the regional enterprises and organisations fail to perform the functions of attraction and retention of highly qualified workers.

The interdisciplinary research carried out within the project framework demonstrates the presence of significant mismatch of the ideas of the quality of life of the key active population groups of the region (B. Khasan, I. Vorontsova, L. Novopashina, 2014).

Around $37.2 \%$ of the population of the region resides in its capital, the City of Krasnoyarsk, which is the administrative centre of the remote extracting industries, where the majority of works is carried out with rotation method. The research carried out by Krasnoyarsk Mayor's office showed that over a half of the respondent citizens do not see any positive changes in their lives (55\%). The absence of prospects and any positive changes in the minds of the majority is caused by the socioeconomic, not the sociocultural context of the city.

The sociocultural context of the city satisfies the majority of its citizens: the appearance and cosiness of the city environment (63\%); cultural life in the city (55\%); communication service quality (48\%); social objects quality (39\%).

The working-age professional outflow from Krasnoyarsk occurs because they do not "see" any opportunities for self-fulfilment and capitalization of their potential. The majority of the citizens are not satisfied with the circumstances determining the employment and self-fulfilment conditions: labour market situation (55\%); financial wealth of the citizens (53\%); economic base of the city (32\%). The socioeconomic situation in the city is aggravated with negative environmental conditions.

The current quality of life tendencies of the region do not create conditions for any effective innovative activity, the key factors of which are, first of all, attractive living conditions for the creative class and demand for innovations from the real sector of economy. "I found out, that, despite the common opinion, the companies would move - or appear in the places of concentration of qualified specialists, not vice versa" (R. Florida, 2005). "Creative professionals, in their turn, do not just concentrate around the place where labour is wanted. They live where they like, and they prefer creative activity centres" (R. Florida, 2014).

\section{Discussion}

From the point of view of the quality of life administration, the priority factor of the living standard is the population's understanding of the territory development prospects and the future of their own personal and professional development, personal self-fulfilment provided that their aspirations are diverse.

Therefore, population occupation modelling in the quality of life context requires considering the factors expressing the territory's capacity for accumulating R\&D founding competences, such as:

1. Proportion of the employed by sectors of economy, not branches of industry.

2. Requirements for the education of workers.

3. Professional and qualification distribution of the employed in the context of R\&D development tendencies. 
4. Occupation and income structure by groups of employees: workers of traditional industrial productions, creative class including the supercreative core and creative professions.

The priority trends for the human capital assets opportunities growth in the Krasnoyarsk Territory (Krai) as a model Siberian region shall be the following:

1) Development of institution conditions for coordination of opinions of the authorities, businesses and population concerning the quality of life including labour quality of life, in order to increase the quality of solutions in the sphere of creating attractive life conditions for the highlyskilled specialists, stimulation of innovative processes and professional composition of the regional settlements.

The professional composition model in the quality of life management aspect, developed within the project supported by RHSF, consists of three subsystems:

a- Reflecting the average annual volume of labour resources by economy sectors with a breakdown to education levels;

b- Reflecting occupational structure of the employed divided into the following groups: workers of traditional industrial enterprises, creative class, including supercreative core and creative professions;

c- Reflecting occupational structure of the employed by the types of the new economy's professions.

2) Provision of high quality communication between social partners of the labour market, in order to achieve consensus in both modernization and working condition issues, education programmes and reduction of structural mismatch found on the labour market and expansion of capitalization opportunities of the human capital assets.

3) Formation of actual competences of the population in the sphere of networking, cooperation, involvement in various forms of social activity, and, most important, in the administration sphere. It is possible within the human potential development programmes run in different territories of Russia using collaboration resources to establish rational balance between the formal education level and the people's labour productivity.

4) Improvement of institutional conditions of integration of science, education and production, stimulation of the industrial manufacturers' demand for innovations and, as a consequence, demand for new professions of the fifth and sixth technological waves laying the foundation for the sustainable development of the city economy. Formation of an Innovative Scientific and Educational Facility in the city based on the network cooperation principles.

\section{Conclusion}

In the high competition, globalization and informatization of the current economy, human potential of Siberian regions predetermines the prospects of its strategic development by means of innovations and superiority centre formation. Along with that, the Krasnoyarsk Territory (Krai), rapidly growing due to the great number of migrants from the neighbouring countries, forms a regressive population structure with the high level of brain drain, especially among the youth, decrease in the real income of the population and the resource potential of the population. The Krai invests various resources to develop the human potential, while the population, especially highly educated youth, prefers to fulfil their potential in other territories. Together with that, the migration inflow structure does not provide the professional composition required for high quality of life. The authorities cannot dictate enslavement terms to the people, and, therefore, to provide the professional composition required 
for $R \& D$ progress. It is necessary to understand the motives of the people's behaviour, develop stimulus considering the diversity of individual perception of the habitat and living conditions provided by the city and the Krai.

From the point of view of $R \& D$ progress in the territory of the region and in order to provide growth and development of its human capital assets, it is necessary, on one hand, to modernize the professional education sphere, strengthen the scientific and research component in the universities' activity and select the fields for integration of academic institutions, universities and innovative infrastructure of the region; on the other, it is necessary to stimulate civil activity.

\section{References}

Quality of life in the Krasnoyarsk territory and a problem of human capital formation. Bukharova, Evgenia B.; Bronskaia, Elena Iu.; Vorontsova, Irina P.; Vitkovskaia, Ludmila K.; Pozdeev, Aleksander N., In: Journal of Siberian Federal University. Humanities \& Social Sciences 11 (2015 8) P. 2237-2247

Scimago Institutions Rankings. Access: http://www.scimagoir.com.

Innovatsionnaia strategiia razvitiia Krasnoiarskogo kraiia. Krasnoiarskiy kray. Ofitsial'nyy portal [The Krasnoyarsk Territory (Krai) Innovative Development Strategy. The Krasnoyarsk Territory (Krai). Official portal] Access: http://www.krskstate.ru/innovation_science/strategy

Territorial'nyy organ federal'noy sluzhby gosudarstvennoy statistiki po Kranoiarskomu kraiu (Krasnoiarskstat) Press-vypusk ot 29.05.2015, No.1-11/13625. [Press Release of 29.05.2015, No. 1-11/13625. Territorial Body of the Federal Service of State Statistics for the Krasnoyarsk Territory (Krai) (Krasnoyarskstat)].

Professional'no-strukturnye $i$ psikhologicheskie aspekty modeli upravleniia $i$ monitoringa kachestva zhizni v regione [Professional, Structural and Psychological Aspects of the Living Standards' Administration and Monitoring in the Region] / Vorontsova, I.P., Khasan, B.I., Novopashina, L.A. Krasnoyarsk: Siberian Federal University, 2015, 152 p.

Official Website of the Ministry of Education of the Krasnoyarsk Territory (Krai) http://www. krao.ru/rb-topic_t_1.htm

Sen, A. Ob etike i ekonomike [On Ethics and Economics]. Moscow, Nauka, 1996.

Florida, R. Kreativnyy klass: liudi, kotorye meniaiut budushchee [The Rise of The Creative Class and How It's Transforming Work, Leisure, Community and Everyday Life] Klassika-XXI, 2005. $430 \mathrm{p}$.

Florida, R. Kto tvoy gorod? Kreativnaia ekonomika i vybor mesta zhitel'stva [Who's Your City?: How the Creative Economy Is Making Where to Live the Most Important Decision of Your Life]. Strelka Press, 2014. 


\section{Вложения в развитие человеческого потенциала сибирских регионов: \\ инвестиции в профессионалов «на экспорт» \\ или рост человеческого капитала территорий?}

И.П. Воронцова, Л.К. Витковская

Сибирский федеральный университет Россия, 660041, Красноярск, пр. Свободный, 79

Статья посвящена проблеме формирования человеческого капитала территорий Сибири и Арктической зоны на примере Красноярского края.

Ключевые слова: человеческий капитал, качество жизни, профессиональная композиция поселения.

Исследование выполнено при финансовой поддержке Российского гуманитарного научного фонда (РГНФ). Проект «Методические подходы к мониторингу миграчионных потоков для формирования системы управления качеством жизни населения регионов Сибири и развития дифференцированной территориальной политики страны». Проект № 15-12-24008.

Научная специальность: 08.00.00 - экономические науки. 